\title{
SPECTRAL MEMORIES: AESTHETIC RESPONSES TO THE FINANCIAL CRASH IN ICELAND 2008
}

\section{Vera Knútsdóttir}

\begin{abstract}
In October 2008, one of the largest bank crashes in history struck Iceland, a country of three hundred and thirty five thousand inhabitants. The aim of the article is to examine two cultural responses to the crash and the crisis that followed. More precisely, the aim is to analyse how the creation of the haunted house in I Remember You, a crash-horror story by crime writer Yrsa Sigurðardóttir, as well as the spectral half-built houses portrayed by visual artist Guðjón Ketilsson refer quite directly, yet spectrally, to the period. The spectral themes of the two works give the opportunity to discuss the moment following the crash as a moment of haunting-but who is haunted and by whom?
\end{abstract}

\section{KEYWORDS}

Economic Crisis, Identity Crisis, Spectrality, Cultural Memory Studies, Literature, Visual Art

\section{INTRODUCTION: "GOD BLESS ICELAND"}

In October 2008, one of the largest bank crashes in history struck Iceland, a country of three hundred and thirty five thousand inhabitants. ${ }^{1}$ The crash was caused, among other things, by the overheating and overexpansion of the Icelandic financial market and the excessive risk-taking by Icelandic investors. It led to a severe financial crisis, accompanied by a crisis in foreign diplomacy due to the Icelandic banks' enormous foreign debt. ${ }^{2}$ It also led to mass protests and the biggest demonstrations in the history of Iceland, the Pots and Pans Revolution, where people came together every day for several weeks to demand the resignation of the government and the head of the central bank. ${ }^{3}$ Many Icelanders associate the key moment of the collapse with the speech made by Prime Minister Geir H. Haarde on October 6, 2008. The Prime Minister rather sombrely described the impending national bankruptcy and ended his speech with the words "God bless Iceland." The expression, which is not a routine political utterance in Icelandic politics, suggested that Iceland 
was all of a sudden placed in an unforeseen turmoil, with no possible solution in sight.

Even though academics have analysed the political and historical texts that deal with the crash in the Icelandic context, less attention has been paid to the artistic response to the events and how the economic expansion, crash, and crisis influenced and were reflected in fiction and visual art from the period. 4 The article aims to examine two cultural responses to the collapse of the Icelandic economy in 2008. More precisely, the aim is to analyse how the creation of the haunted house in I Remember $Y o u$, a crash-horror story by crime writer Yrsa Siguroardóttir ${ }^{5}$, as well as the spectral half-built houses portrayed by visual artist Guojón Ketilsson, refer quite directly, yet spectrally, to this historical period. 6 The spectral themes of the two works give the opportunity to discuss the moment following the crash as a moment of haunting-but who is haunted and by whom?

\section{THE SPECTRAL SPACES OF THE ECONOMIC CRISIS}

Guojón Ketilsson's series of drawings (Fig. 1, 2, 3) of half-built houses were a part of a larger exhibition titled Hlutverk or Roles, at the ASÍ gallery in Reykjavík in 2009. The photo-realist drawings portray the half-built villas on the outskirts of Reykjavík. The strange unfinished state of the houses is a consequence of the economic crash. Or, rather, it is a consequence of progression from the economic expansion that initially made the construction of these houses possible to the crash that called for the sudden stop of the constructions and, finally, to the crisis where the suspended development and indefinite waiting becomes the new status quo.

The decision to represent the houses with a drawing instead of a photograph emphasizes the role of the artist in depicting the world. The fact that Ketilsson chooses to focus on these half-built houses and to spend the time laboriously drawing them suggests an urgency and claims the attention of the viewer. In this sense, the drawings become the carefully constructed aides de mémoire: while in real life these empty structures will eventually become houses, or perhaps the opposite, torn down and removed from the urban space, their artistic representation will live on as documents about this period in cultural history. By creating carefully constructed representations, the artist asks for their inclusion in cultural memory, where they will live on, either as works that become part of the canon and are regularly on display in the museum galleries, or carefully hidden from view and preserved in the museum archive or storage: the cultural unconscious. 


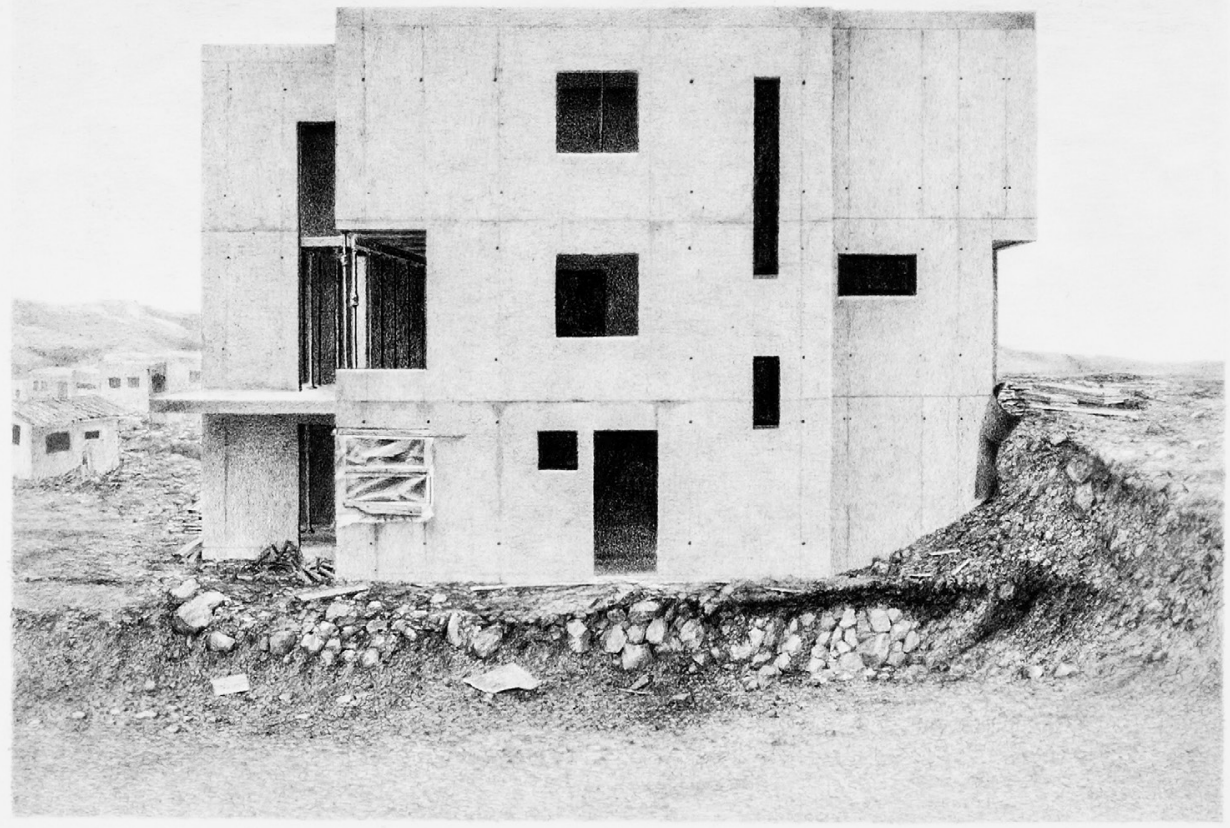

Fig. 1

Guðjón Ketilsson, untitled, 2009 , pencil on paper, $40 \times 40 \mathrm{~cm}$.

Courtesy of National Gallery of Iceland 


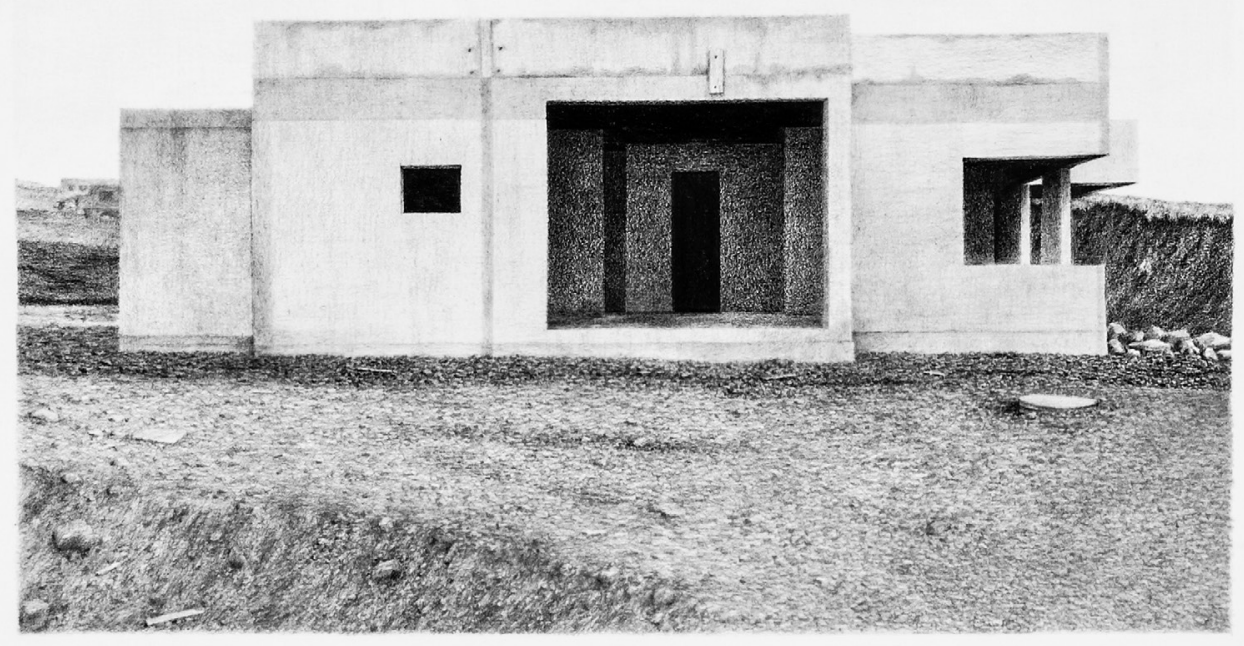

Fig. 2

Guðjón Ketilsson, untitled, 2009 , pencil on paper, $40 \times 40 \mathrm{~cm}$.

Courtesy of National Gallery of Iceland 


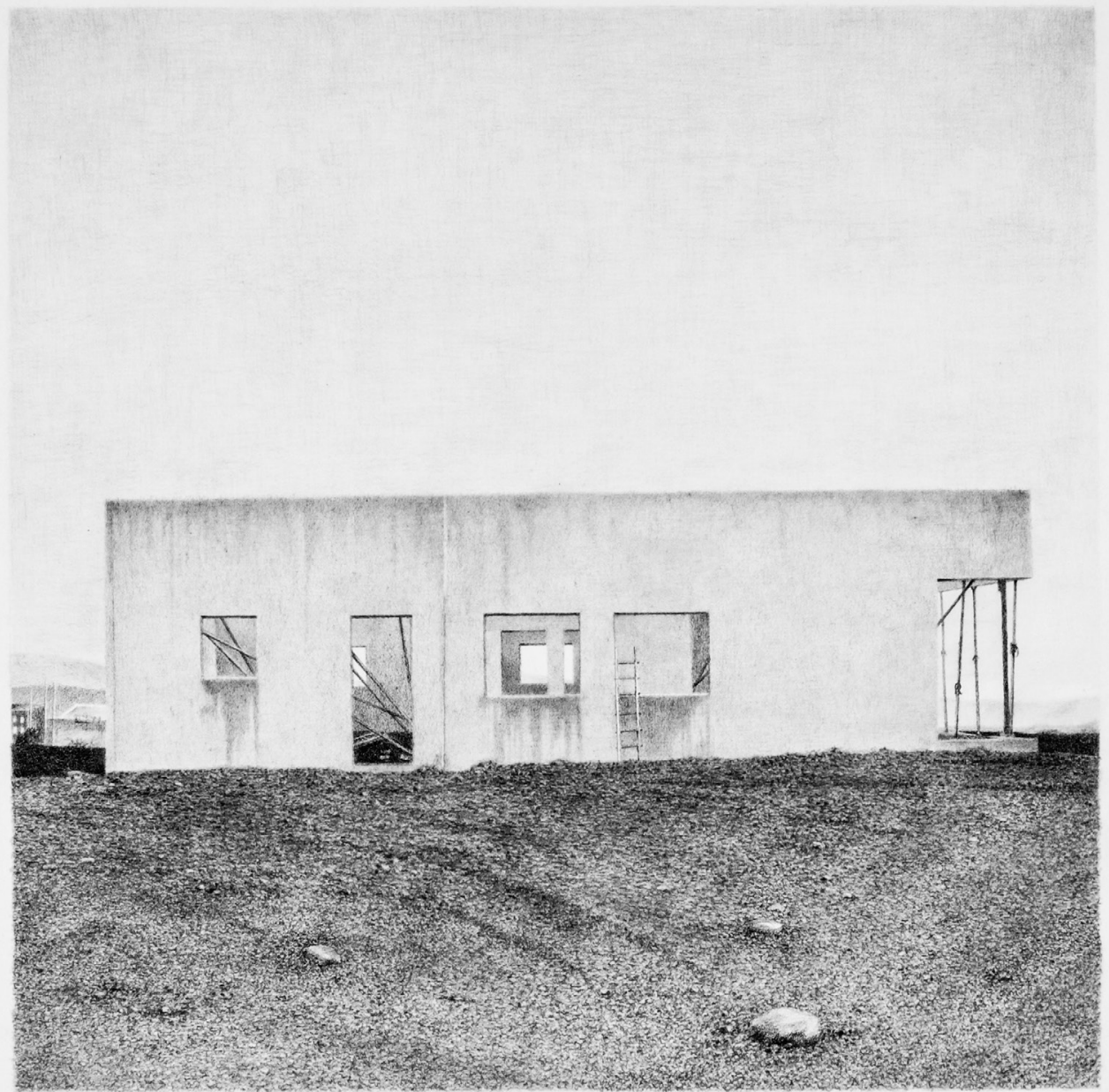

Fig. 3

Guðjón Ketilsson, untitled, 2009 , pencil on paper, $40 \times 40 \mathrm{~cm}$.

Courtesy of National Gallery of Iceland 
The light in the pictures is soft and bright, illuminating the otherwise bare dark grey structures, reminiscent more of chunks of concrete than spaces meant for family life. The nakedness of these houses further suggests their vulnerability in the face of the elements: winds, rain and snow. The image clashes with the warmth and security usually associated with the home. On some of the drawings, one can see pillars, wood, and other material supposed to sustain the structure and ladders to access the floors above the ground floor. The background sometimes divulges the surrounding environment that either evokes rural spaces with lakes and empty fields or the beginnings of a new neighbourhood with other empty houses in the distance. Pieces of wood and other construction materials lie on the ground around the houses indicating this is a construction area that is neither welcoming nor safe for anyone other than construction workers. These isolated houses are anything but homely and domestic.

The series expresses a certain period of emptiness in the city, calling to mind the idea of ruins. These houses never got to the stage of containing human life but immediately moved to the stage of 'after-life' by becoming slowly decaying urban ruins. Decay and ruin are a fundamental trait of the gothic aesthetics expressing the uncanny, the spectral and the haunting. Richard Davenport-Hines describes how the original British goths were fascinated by architectural ruins and how that fascination disseminated over the years to more symbolic forms of ruins such as moral ruin (evil monks), corporeal ruin (physical decay), hereditary emotional ruin, as well as socio-political ruin (ethical void): "Gothic's obsession with decay, and its tradition of political negativity, makes it at the end of the twentieth century an aesthetic of defacement."7 The drawings by Ketilsson capture the capitalist ruins of the post-crash society where the architectural ruin represents the ideological ruins of the period. The drawings express how the urban space reflects the crash of the economic system as well as symbolising the downfall of a certain ideology: how the prosperous and booming economic expansion came to a sudden end and, with it, the faith in the long-standing tradition of the national heroic ideal. These ruins are haunted spaces and the following analysis will focus on what constitutes the haunting, as well as asking who is haunted and by whom?

\section{THE HOUSE AND THE HUMAN SUBJECT}

The parallels between the house and the human body are emphasized when the former is stripped down to its simplest 
form. The drawing suggests a relation to the viewer who herself experienced the aftermath of the economic crash and shares those memories with a bigger collective: not only with the other inhabitants of Reykjavík and Iceland, but also in the transcultural sense, with inhabitants of, for example, Spain and Ireland. Here, the relation between the self and the home are manifested: the crash brought forth the anxiety of losing one's home as well as losing one's identity, where the home becomes a symbol for both personal and collective senses of identity-an entity that ties a social group to a certain geographical location: family and home, nation and country.

The drawings made by Ketilsson, however, do not only evoke the possible inhabitants of the half-built houses. They also indicate the workers who lost their jobs before completing the construction of the houses. The artist's endurance and long working hours perceivable in the detailed work of the drawings as well as the parallels with the human body suggest yet another human subject related to the reality portrayed, one who is absent from the images: that of the construction worker who spent long hours building the structure. During the prosperity era in Iceland, physical labour was left to numerous migrant workers. Some of them left during the crisis but others stayed, and their part in restoring the finances of the country should not be underestimated.

The idea of the invisible migrant worker evokes Esther Peeren's discussion on living ghosts and spectral agency in her book Spectral Metaphor: Living Ghosts and the Agency of Invisibility. ${ }^{8}$ Peeren draws on Derrida's discussion in Spectres of MarX on how capitalist society spectralizes human subjects. ${ }^{9}$ Here, the spectre is not someone returned from the past, it is a person who is overlooked and ignored in the present: someone expendable, marginalised and dispossessed.10

In traditional narratives of haunting, ghosts have various representational functions and levels of visibility and presence, they can either be powerful or weak. Peeren describes, for example, how Derrida associates the ghost with powerful agents and systematic forces as well as with the dispossessed subjects these systems produce. ${ }^{11}$ The former conforms to the idea of the ghost as a sovereign power, following the model of the father ghost in Hamlet, the central metaphor for Derrida in Spectres of Marx. The father-ghost violently haunts the living and has no problem moving between places and making himself heard. Derrida therefore uses him as a metaphor for the 'ten plagues of the new world order' and mentions, for example, unemployment, free market ideology, 
the arms industry and trade, the mafia and drug cartels. ${ }^{12}$ The other example of spectral subjects are figures of vulnerability: the subjects that are exploited by the aforementioned sovereign systematic forces. Or, as Derrida states: "the ghosts who are not yet born or who are already dead, be they victims of wars, political or other kinds of violence, nationalist, racist, colonialist, sexist or other kinds of exterminations, victims of the oppressions of capitalist imperialism or any of the forms of totalitarianism."13 The vulnerable spectre is not only produced by the sovereign spectral system but also, according to Peeren, struggles against it: "The vulnerable ghost struggles against the spectralizing system by which it is produced as invisible and irrelevant."14 Peeren further refers to Antonio Negri and his article "The Specter's Smile" which the author wrote as a critical response to Spectres of Marx. ${ }^{15}$ The spectre, for Negri, offers the possibility of examining the phenomenology of capitalist production and announces a process of alienation and estrangement in the spirit of the uncanny: "A specter is the movement of an abstraction that is materialized and becomes powerful: above all the abstraction of value which, in a bloodless movement, vampirizes all of the worker's labour and, transforming itself into surplus-value, becomes capital; money, secondly, which in a circular movement verticalizes itself and is consolidated into currency."16

In this way, the drawings by Ketilsson become haunting in more than one sense. Following Peeren's and Negri's discussion of the living spectre of capitalist society, I argue that the half-built houses are haunted by the invisible worker who started building them, and whose labour was "vampirized" during the prosperity years of the economic boom. The absence of the worker from the images raises questions about his whereabouts in the present and his status in the post-crash society. According to this reading, it is the absent spectre who renders these houses haunted. However, the houses can also be considered spectres themselves. They evoke visual connotations with the classical form of the whitesheet ghost and they channel, visually as well as spatially, the uncanny impacts of the collapse and crisis on society. While according to Negri, the invisible worker is unable to haunt capitalist society, the spectral half-built houses become concrete and spacious memorials to the temporary crash of capitalism: in other words, they become capitalist ruins par excellence. Their concreteness, along with their half-built unfinished state, support and suggest the persistence of that spectral and haunting memory. The spectral reading of these drawings enables the question of 
what it really is that haunts these drawings, and allows one to focus on something that is not present in the image-an absence. These drawings are extremely melancholic, signalling the loss and impossible mourning for a collective future. When one thinks about the invisible workers who undertook the hard labour during the prosperity years and built the half-built spectral and unhomely houses, certain questions are raised: for whom was the pre-crash future destined?

\section{INTERLUDE:}

THE TWO DIMENSIONS OF THE CRASH AND CRISIS IN ICELAND Historian Valur Ingimundarson describes the crash as a 'collective shock' and the most profound since the founding of the Icelandic Republic in 1944. ${ }^{17}$ In the weeks following the prime minister's speech, politicians constantly referred to the events as if it were a natural phenomenon, some kind of bad weather, a storm that the nation had to pull through and unite against. Thus, when asked about the responsibility in the wake of the crash, politicians were quick to state the importance of not personifying the problem but rather uniting against it: emphasizing the need for unity during moments of crisis instead of looking for culpable individuals and pointing fingers at possible wrongdoers. ${ }^{18}$

In recent years, it has become more and more evident how the events of collapse and crisis have been met with a certain passiveness in the political domain, as there seems to be no agreement on the political responsibility in the course of the events, and the reforms promised in the wake of the Pots and Pans Revolution have also been severely limited. Ingimundarson writes of "selective justice and failed political reform" in Icelandic postcrash society, while Gunnpórunn Guômundsdóttir describes how people seem to want to forget about the movement: "despite the success of the protests, people do not seem to have a need to memorialise and celebrate the Pots and Pans Revolution for a variety of reasons. Perhaps this is mainly as a result of the sense of disappointment with the limited reforms that have been accomplished since." 19

The most obvious example is the political reaction to the "truth report' written by an independent committee commissioned by the state to investigate the causes of the crash. ${ }^{20}$ When the report was published in 2010, "it proved to be highly critical of domestic political and financial elites”, underlining the responsibility of politicians in charge at the time: ministers from the rightwing Independence Party in office both during the period of 
economic expansion that led to the crash and during the crash itself, as well as political agents from the Progressive Party and the Social Democrats. ${ }^{21}$ Ingimundarson, furthermore, describes how, at the time of publication, the report became a 'foundational document' for the collective identity in Iceland by creating a sense of cohesion among the Icelandic people during unstable times, but at the same time how different groups came to interpret it in their own interests: for the left the report proved the culpability of politicians, for the right the corruption of bankers. ${ }^{22}$ With the passing of time, as no one mentioned in the report admitted their responsibility, it slowly lost its status as a unifying document, and has largely been forgotten.

The crash and crisis of 2008 have two dimensions in the Icelandic context; economic and mnemonic. The economic dimension describes how the nation went almost bankrupt in a matter of days. The second dimension describes how the economic collapse brought forth a different kind of crisis; that of memory and identity. This 'mnemonic crisis' was caused by the way in which the crash brought down the collective national ideal of the "business Vikings" and, thus, the yearlong tradition of constructing a singular, unifying, proud and heroic nationalistic masculine national identity in Iceland.

The collective memories of the crash are above all contested, meaning that people hold different views on the events of the collapse, its causes and effects. ${ }^{23}$ The crash therefore strongly evokes politics of memory and of identity, as the two are tangled up in manifold ways. As John R. Gillis explains: “The parallel lives of these two terms [memory and identity] alert us to the fact that the notion of identity depends on the idea of memory, and vice versa. The core meaning of any individual or group identity, namely, a sense of sameness over time and space, is sustained by remembering; and what is remembered is defined by the assumed identity."24

In Útrásarvíkingar! The Literature of the Icelandic financial crisis, Aleric Hall stresses the anxieties brought on by the crash as a form of post-colonial anxiety that mostly concern Iceland's place in the world in imperialist terms-as a victim, participant, and beneficiary. ${ }^{25}$ Ingimundarson states that the Icelandic people had usually taken on the role of victims in external or foreign interference: first in light of colonialism, as a Danish colony, then during the British and later American occupation during World War II, and again in the Cod Wars against the British from 1950s to 1970 s. 26 
After the collapse, Icelanders could no longer play the part of the victim, since their image changed into that of the perpetrators of the economic distress for hundreds and thousands of people. ${ }^{27}$ Anthropologist Kristín Loftsdóttir states that the economic crash undermines the national identity Icelanders have created for themselves, as being a superior kin with direct lineage to Vikings-the true heroes of the ancient Nordic world. ${ }^{28}$ Guoni Elísson describes how the discourse, imagery, and symbols of the expansion refer back to the literature of heroes in the Icelandic sagas, establishing an essence and a nature for the Icelandic stereotype, whose roots lie in the physical and mental abilities of heroes of the Middle Ages. ${ }^{29}$ Elísson explains how the Viking image was both supported by the politicians in speeches and discussion in the media, as well as by the businessmen themselves, who used Viking symbols for their own branding. ${ }^{30}$ This idea of the Icelandic "business Viking” (ice. Útrásarvíkingur) can only be understood, according to Loftsdóttir, in the context of nationalism that originates in the Romantic period and with the birth of the nation: when the Icelandic people started fighting for independence from the Danish crown. ${ }^{31}$

Loftsdóttir has examined the nationalistic images and ideas about superiority that can be found in Icelandic schoolbooks written during the first and second decades of the twentieth century and used in elementary schools for the next seventy to eighty years. 32 The textbooks, such as two books both titled Íslandssaga (e. History of Iceland), were aimed at children in elementary school, and described the origin of the Icelandic people as being the "crème de la crème" of the Nordic nations. ${ }^{33}$ She further describes these ideas as "spectres of the past" that appear as revenants during the economic expansion and are adjusted to the values of the contemporary globalised society. ${ }^{34}$ The schoolbooks not only depict a discourse on the superiority of the Icelandic nation but also portray the story of its people as the story of Icelandic men, hardworking and righteous, who built the country. ${ }^{35}$ The crash therefore initiated a certain (temporary) 'fall' of masculinity and a related phase of 'hurt' masculinity.

Cultural memory studies tend to focus on contested memories; memory that is challenged and questioned by its blind spots, framing trauma at the core of memory studies as a form of memory that refuses to be narrativized. ${ }^{36}$ Hall discusses how the events of the crash have been compared to traumatic events, such as the 9/11 attacks in the USA, and the prime minister's expression, "God bless Iceland”, evokes the sentiment associated 
with speeches made by the US president at that moment in time. ${ }^{37}$ However, instead of defining the crash as a national trauma and comparing it to large-scale terrorist attacks such as 9/11, I argue that the crash represents an event that challenges memory and highlights its dynamics, offering the opportunity to question its construction and expose its workings. ${ }^{38}$ In terms of spectrality, the crash represents a certain blind spot of memory that is not dealt with but repressed, and returns because it refuses to be forgotten. The crash is therefore a strong example of a spectral memory.

In Specters of Marx, Derrida draws connections between hauntology and politics of memory: "So it would be necessary [...] to learn to live with ghosts, in the upkeep, the conversation, the company, or the companionship, in the commerce without the commerce of ghosts. [...] And this being-with specters would also be, not only but also, a politics of memory, of inheritance of generations.”39 I define spectral memories as memories that have been momentarily forgotten, silenced or repressed in the cultural psyche, but have returned to the public realm by means of artistic production, literature and art. The spectral return represents a transformative dynamic exchange between memory and recipient, and offers the potential to critically reflect on the past in order to work towards a better future.

While there are consonances between the two, and while the spectre has been employed as a metaphor for trauma, to the point that Roger Luckhurst calls it a cliché, not all spectral memories are necessarily traumatic. 40 Not all forgotten memories are traumatic memories, just as matters that somehow escape memory, refuse to be easily narrativized and memorialised, are not all inflected with trauma or the products and aftermaths of traumatic events. Furthermore, it is not fitting, in my opinion, to refer to the financial crash in Iceland as a traumatic event, because that simplifies it to a certain extent: while the impacts of the crash were traumatic for some, who, for example, lost their jobs, homes and health due to economic concerns, for many others the collapse of the banks represented rather a "mnemonic disruption", i.e. a collective ideological shock, than a violent or physically harming event. The economic collapse initiated a loss of the national ideal and collective future, framing the period of crisis as period of haunting and spectral mourning.

In Sigmund Freud's frequently quoted text 'Mourning and Melancholia,' the term 'mourning' reflects a certain 'healthy' process of grief, where the subject ultimately overcomes the 
loss. 41 'Melancholia,' however, represents the opposite, a certain failure of that process, where the subject cannot overcome the loss and is therefore bound to be in a state of endless mourning, or melancholia, which shares symptoms with what today is termed depression. Freud's text has proven to be a seminal point of departure for contemporary scholars writing about societies in mourning and in the aftermath of collective shock.

The impact of Freud's article is evident in Panic and Mourning: The Cultural Work of Trauma, a collection of articles where the editors define mourning in their introduction as follows: "Whereas panic tends to crop up during the experience of violent events, mourning, on the other hand, relates to the aftermath of a brutal disruption and to the way humans try to make sense of it retrospectively." 42 The collapse of the banks in Iceland was a moment of such 'disruption' followed by a period of mourning where people tried to make sense of what has happened. The authors of the articles are post-Freudian in the sense that they use Freud's text to think beyond the distinction of mourning versus melancholia. They are suspicious of the 'successful' and progressive process of mourning, and have opted for melancholia as a more ethical way of compensating loss and remembrance. ${ }^{43}$ The authors further write about a "refusal to mourn” which they relate to thinkers such as Derrida, "who equates conventionalised mourning with an unethical and politically troublesome forgetting of that lost," expressing important connotations between melancholia and spectrality. ${ }^{44}$

While one could simply conceive of this new idea of ethical mourning as melancholia, I would like to use the term spectral mourning which indicates how the subject is haunted by the loss, and how in the spirit of spectrality, he or she allows this haunting to take place, even wants it to take place, as a possible transformative memory encounter. While melancholia is a state that is constantly looking back to the past, spectrality emphasises the ghost as both a 'revenant' and an 'arrivant'_coming from the past as well as announcing what will come, indicating how the reading of the past affects the future: "studies of ghosts and haunting can do more than obsessively recall a fixed past: in an active, dynamic engagement, they may reveal more than the insufficiency of the present moment, as well as the disconsolations and erasures of the past, and a tentative hopefulness for future resolutions." 45

The aim of the following analysis of the crash-horror fiction I Remember You is to focus on the haunting, how it is represented and how it is responded to, in order to examine how it relates 
to or embodies the character's process of mourning: what are the reasons behind the haunting and why are these characters haunted? In addition, how do the hauntings precisely relate to the financial crash: to the economic crisis as well as to the mnemonic crisis of memory and identity? How do the characters react to the ghost and respond to their feelings of loss? Are they melancholic, nostalgic, constantly looking back to brighter and better times? Or do they use the potentiality of this spectral state of mourning to learn from the mistakes of the past in order to look towards the future?

\section{REMEMBER YOU:}

\section{HAUNTED HOUSES IN THE TIME OF ECONOMIC CRISIS}

In the wake of the banking crash, crime author Yrsa Siguroardóttir changed her narrative form and started writing horror novels about hauntings and hidden secrets in the post-crisis settings. These uncanny crime novels were among the most popular reading material during the financial crash and turned the author into one of the major crime novelists in the country. 46 Sigurðardóttir was already an acclaimed crime writer whose contemporary realist crime and detective novels were popular with Icelandic readers as well as readers abroad, as her novels had at that point already been translated and published widely. I Remember You, the focus of the analysis here, is perhaps the most widely read of Siguroardóttir's crime novels, whose film adaptation premiered in 2017.47 Even though one part of the narrative revolves around an unsolved crime and inexplicable murders, I Remember You is more of a horror and a gothic ghost story, with an emphasis on haunting, ghosts, and revenants who return to the world of living with messages from beyond the grave. Like other ghost stories by Siguroardóttir from the same period, references to the real events of the economic crisis are combined with uncanny themes, creating an atmosphere of anxiety and distress. In many of these works, the home, the domestic space of security and warmth, is under attack, symbolising people's fear in times of financial crisis they will actually lose their homes.

I Remember You has two plotlines, two stories that are interwoven and converge in the end. In the following analysis, I will focus on the plotline that revolves around three characters-a married couple, Katrín and Garoar, and their female friend, Lífwho have purchased together and plan to repair an old abandoned house in a remote village called Hesteyri in the Glacier Fjords in Iceland's Westfjords. Katrín and Garôar are on the verge of 
bankruptcy due to the collapse of the Icelandic banks, Garoar's unemployment-significantly, he had been a banker-and their household debts. The purchase of the house in Hesteyri is originally the husband's idea: he wants to renovate it into a guesthouse for hikers and tourists in the area. The renovations are therefore a way for him to get back into business and make money, in order to regain his former identity as a successful businessman. However, it appears as a rather desperate way of recovery considering that he has very limited understanding of renovation work, and even less of the Hesteyri area.

The renovations take place during winter, as the owners want to be in business for the summer. An old captain sails with the trio and Líf's little dog Putti out to Hesteyri. The captain is surprised by how little they know about the place and seems anxious about them staying there alone at this time of year. He tells them that the house they just bought goes under the name of 'Final Sight', and how he is very suspicious of it, suggesting that the abandoned dwelling might in fact be a haunted house in the most classical sense. He also tells them how isolated the area is: there is no electricity, no phone reception, the next farm and town are both very far away, and in bad weather it is impossible to access the village by boat.

The characters have not stayed in the house for long when they understand that they are not alone in the area. Initially they believe that a mentally disturbed child is terrorizing them. As the narrative progresses, it becomes clear that the child is a hostile ghost who seems to have returned for revenge, destroying all their plans of restoring their finances and recovering their losses.

Katrín is the focal point of this plotline as she narrates the story to the reader who sympathises with her position. As the story develops, she becomes a victim of her husband and their friend, who turn out to be lovers and have planned to kill her in this remote area, and make it look like an accident to acquire her life insurance. ${ }^{48}$ This implies that the ghost might be a 'good' ghost, who sympathizes with the victim, as some of the messages that he leaves around might be read as warnings. Towards the end, however, when Garðar has disappeared, the ghost attacks the two women, killing Katrín and causing Líf severe injuries. At the end of the story, Lif is saved by the police and taken back to civilisation, only to die from her injuries a couple of hours later. The rescue squad does not find Katrín's remains and the final paragraph in the story describes how she has herself become a spectral subject, a ghost that remains in the house in Hesteyri. At 
that point, the reader gets a brief chance to look at the story world from a spectral viewpoint, following Katrín's ghostly focal point.

While the hauntings take place in different locations in Hesteyri, the house where the trio resides seems to attract the spectral presence of the ghost. The haunted house echoes Freud's statement on how repression transforms the home into an uncanny space, as it appears, at first sight, to be a 'normal' house: "This uncanny is in reality nothing new or alien, but something which is familiar and old-established in the mind and which has become alienated from it only through the process of repression." 49 On one hand, there is nothing in the appearance of the house in Hesteyri that suggests that it is haunted. On the contrary, it seems to be a fairly ordinary house. On the other hand, it has a certain uncomfortable aura to it: "Even the house, which was in every way a very charming old fashioned Icelandic wooden house, seemed oppressive [...] as it stood there silently, daring them to knock on the door." 50 Before they actually see the ghost, the hauntings are evoked with sounds and smells. The eerie 'creaks in the pine' express how the ghost makes its presence known with dins in the house's woodwork, as if someone was walking around. First, the ghost appears as a shadow, evoking his bodyless state as a spirit or spectre. In other scenes, the ghost is described as a dark silhouette. ${ }^{51}$ However, as the hauntings intensify, the ghost acquires a body, which makes them think that they are dealing with a living person and not a superficial creature. Besides, the characters are not at all aware that they are, in fact, being haunted by two ghosts, nor is the reader, who believes that they are dealing with only one hostile creature.

Both ghosts turn out to be young boys who went missing but at different times; Bernódus, who was bullied by his schoolmates, disappeared sixty years before, while Benni got lost playing hide and seek with his friends a few years before the story takes place. For seemingly unrelated reasons, both boys, or their bodies, ended up in the house in Hesteyri or nearby. Bernódus was clearly an outsider during his life, neglected by his father, bullied by his peers, and picked on by his teacher. His status as an 'oppressed other' is further highlighted by the fact that no one came for him when he went missing in Hesteyri. It is thus clear that he returns for two reasons. The first is revenge: to get even and kill the people who treated him badly in his life. This turns Bernódus into a hostile creature, a gruesome ghost, and therefore uncanny in the Freudian sense: "[m]any people experience the uncanny in the highest degree in relation to death and dead bodies, as well 
as to the return of the dead, to spirits and ghosts." 52 However, Bernódus also seems to return for a different reason, as his hauntings point towards his corpse in the basement, encouraging the human subjects to look beneath the surface, in the basement, and identify the body that would eventually solve his case and eliminate the uncertainty about his death. This makes Bernódus a spectral ghost in the Derridean sense; the ghost who returns with a message and seeks justice for matters that have been forgotten.

The ghost of Benni does not seem to return for revenge but haunts the house because of the uncertainty of his death that continues to haunt his parents. This makes Benni a friendlier, more passive ghost than Bernódus, who is not only aggressive and violent but also powerful, capable of entering the locked house, of moving between different places in the country to kill his victims, of entering their minds and dreams, and of affecting electrical appliances and drying out batteries. In the final haunting scene, readers come to understand the presence of the two ghosts, and how one of them is not capable of entering the house: "She recoiled in horror, feeling hope drain away, for outside stood a boy who didn't seem to be the same one as they had seen before. This one, who was smaller, stared in with glazed eyes, his greyish face infinitely sad. ${ }^{53}$ However, Katrín is also scared of this ghost, and sure that it wants her dead, as his apparition leads her to believe that the place in its entirety is doomed: "Outside or inside. It didn't matter. They were dead.”54

Katrín's reaction to the two ghosts is steeped in the uncanny gruesome feelings towards the return of the dead, as she seems unable to move beyond her feeling of fear and ask herself why these two spectral beings have returned to precisely this place. Initially, I Remember You, is a story about repression and what happens when multiple responsibilities are subdued and not dealt with. The novel thus mirrors the multiple dimensions of the crash in the Icelandic context by addressing both the period's economic problems as well as the identity politics of the time. The economic crisis sets the stage for a juicy crime story implying how financial troubles can drive people to desperation and provoke them to commit dark deeds. The mnemonic crisis, on the other hand, is addressed allegorically through the interplay of the characters, and in the dynamic of struggle between their different identities. Analysing the different reactions of the characters towards the spectral presence might help to understand the significance of the hauntings for the narrative, as well as for the broader context. 
The convoluted nature of the plot line can to a certain extent be explained by the form of the narrative and how it relates to the gothic tradition, the ultimate genre of hauntings and ghosts, which, as Davenport-Hines states, contains "four hundred years of excess, horror, evil and ruin." 55 He further elaborates: "Goths unfortunately seldom rank sanity or calm among the highest aesthetic achievements; nor do gothic's millions of contemporary artistic consumers. They like carefully staged extremism, and vicarious or strictly ritualised experiences of the dreadful Other.”56 In this sense, the excess of I Remember You, along with its other traits such as the 'cruel hero-villain', 'cringing victim' and 'a terrible place, some locale, hidden from public view', turn it into a gothic novel par excellence. ${ }^{57}$ Davenport-Hines furthermore defines the gothic as an expression of 'counter-enlightenment' as an emotional, aesthetic and philosophical counter-reaction against the age of reason prevalent in the eighteenth century, and against society built on hierarchy and regulation. 58 Gothic imagery, according to him, has to do with transgression against authority and the central focus of 'gothic revival' in the twentieth century is used to illustrate power relationships; to display economic authority, class control and superior status. ${ }^{59}$ This relates strongly to how I Remember You responds to the crash and crisis situation, among other ways, by addressing the identity problematics of the period through the interplay of its characters: where the dominant male characters seek to repress the hauntings, what they stand for, as well as their extended feelings of grief.

While the uncanny emphasises how humans are frightened of ghosts because of their gruesome uncanny nature, and Freud seeks to analyse the reason behind those fears, the spectral emphasises the importance of agency; both for the ghost, what it is and is not capable of, and not least for the human subject who is haunted by the ghost: how do the living react to the haunting? The spectral stresses how living human subjects should approach the ghost as a friendly figure who returns for a reason, and how it is their responsibility to discover these reasons. It is therefore worthwhile to see if this approach applies to the three characters in the story in Hesteyri, and to analyse their reaction, in order to examine how the hauntings refer to the broader context of crash and crisis.

Let's start with Katrín, the main character and focal point of the story, who represents the reader's access to the story world. She appears as an innocent, passive one, who, to a certain extent, 
sympathises with the ghost, or the 'deranged child' as she believes it to be, and is quick to accept the haunting, yet without trying to understand the reasons behind the ghostly return. Katrín is passive because even though she doesn't agree with her husband's plans, she allows him to bring her to Hesteyri under the pretence of the impossible project of repairing a haunted house. She does not even protest because she is afraid to hurt her husband who is already devastated due to his unemployment and crisis-an identity crisis of sorts, since he has lost his status as a successful banker and is trying to restore his pride. At one point, Katrín refers to the house as Garoar's dream which she does not want to ruin with any 'silliness,' as she calls the hauntings. ${ }^{60}$ Katrín therefore passively accepts going to Hesteyri to support her husband and to unite during challenging times. She is furthermore quick to accept the hauntings, and instead of fighting back, she calmly waits for what is to come. This passiveness of Katrín turns her into an ideal post-crisis political subject but also raises certain questions: why is she so submissive and what does this passiveness and absence of agency, the reluctance to react, and letting others control symbolize in a larger context?

Katrín's behaviour can, to a certain extent, be explained by the circumstances of her marriage, and how she, above all, wants to please her husband. Garoar has the idea of repairing the house and bringing them to Hesteyri, to begin with, but he is also in complete denial: both about the ghost as well as about their desperate economic situation. His reluctance to face the situation is perhaps due to his bad conscience. He represses the problems facing him because it helps him avoid admitting his guilt: that he is betraying his wife, not only by cheating on her, but also by planning to kill her to acquire her life insurance. The house project is therefore a decoy for Garoar, even though it might also be a way to restore his identity and become a successful businessman again. Katrín, however, believes it to be a desperate way to recuperate his losses, as he has been unemployed for eight months and deeply desires to get back to work. At one point, Katrín describes how their family pitied them because of his unemployment, emphasising how the economic loss also has to do with pride and shame. For Garoar, the house becomes a symbol of the dream of a better future, and he is not willing to allow some silly ghost to destroy that dream. ${ }^{61}$ When they discover that the phone batteries have suddenly and for no obvious reason died, Garoar says that he cannot deal with that right now: "I've got to pretend this thing with the phones isn't happening. He looked at Líf, and then at Katrín, who recognised 
this reaction all too well; he couldn't cope with this sort of crisis at all." 62 Here, Katrín makes the connection between the situation in Hesteyri and the crisis of the period without realising how deeply desperate Garðar's way to recover his losses actually is.

The story of Garoar, his unemployment, repression, and desperate ways to regain his pride, points directly to the identity problematics caused by the crash and the crisis. His character represents the pre-crash banking greed and the contemporary fall of the twenty-first century global capitalism. However, and more precisely, it also symbolises the downfall of the masculine hero so prevalent in the construction of national identity in Iceland and expressed in the image of the "business Viking" during the pre-crash boom years. The novel challenges this narrative of masculine heroism, by drawing out the weaknesses and flaws in Garðar's character: emphasising his desire and need for repression as well as by turning him into an amoral criminal or villain who is planning to commit murder.

The character of Garoar thus becomes a symbol of the dominant cultural group in Icelandic society, the patriarchy, whose agents seek to repress the crash, its causes and effects, in order to deny and erase their own responsibility and guilt. This is expressed through the relationship between Garoar and his wife, Katrín, who becomes his subordinate and is pressed to follow his ways and decisions even though she does not approve of them. Garoar furthermore actively represses his wife, her warnings and words of caution, even when he knows that she speaks the truth about their critical situation. The marriage of Garoar and Katrín becomes a symbol of a power relationship, where the male violently takes the dominant lead and represses certain traits, such as sorrow, grief, mourning and regret. Garðar is in denial about his feelings of grief, while Katrín mourns their former life. However, because of her husband, she is unable to explore the potentiality of the spectral mourning: to use the present moment to reflect critically on the past and work towards a better future.

The third character, Líf, is very hostile in her reaction towards the ghost as she opts for exorcism to get rid of the ghost, by wanting to kill the disturbed child, and above all, to leave the uncanny location, no matter what: "Just imagine if we could find the little bastard, tie him up and finally have some peace. Maybe we get to kill him, since he obviously killed the man who used to own the house.”63 Líf proves to be an example of an extreme individualist, devoid of all empathy, as she continuously suggests that it is not her job to deal with other 'people's problems', and it is not her 
role to pay the debts of others. When Katrín finds out about Líf's affair with Garoar, she also learns that Líf would never marry him, because she does not want to marry his debts. ${ }^{64}$ Later, towards the end, Lif starts pondering questions of culpability and punishment, as if the ghost had returned to avenge for her personal misdeeds: "do you think if someone does something bad, they always get punished for it?"65 While Garoar represses his feelings of guilt and his bad conscience, Líf seems to be dealing with the absence of conscience and does not admit her wrongdoings until she is threatened by a hostile creature.

At one moment close to the end of the novel, the ghost encourages Katrín and Líf to look in the basement, where they find human bones. ${ }^{66}$ This clarifies the reasons for the hauntings: he wants his dead body to be found, in order to settle his case, so justice can be restored. The hauntings of Benni have similar causes: to connect the haunting with the location, highlighting where his disappeared body is to be found. The story of the two boy-ghosts, as well as of the trio, draws out how the haunted house essentially becomes a symbol for a dark, pessimistic and melancholic (in the traditional sense of the word) attitude towards the future. Instead of allowing the hauntings to encourage them to use the spectral moment for reflection, and for critically looking back, using the crash to learn and examine what went wrong in Icelandic society in the years leading up to the crash, the trio expresses a desire to go back to what passed, as opposed to what could come. This suggests a form of melancholic mourning in the sense of a 'bad' pathological nostalgia: a nostalgia that drives them to desperation, panic and to committing terrible deeds.

Here the question of responsibility rises and the two ghosts, Bernódus and Benni, seem to have two symbolic functions in this regard. The convoluted nature of the plot, the excess, multiple ghosts and hauntings, as well as the fact that the house in Hesteyri is haunted by two ghosts, illustrate the multiple levels of responsibility and guilt for the financial crisis: the economic, in the fact that the nation went almost bankrupt, and the mnemonic, in the sense that the crash brought down the collective national ideal in the form of the "business Viking." The latter expresses the problematics of national identity construction embedded in Icelandic history, which is repressed, and thus keeps haunting.

This mechanism of repression brings us to the second symbolic function of the ghosts: the historical distance of sixty years between the two boy-ghosts which creates the historical long view of the novel. Here, the death and forgetting of Bernódus implies 
how repression works: how repressed matters are bound to return, indicating that the memory of Benni is also bound to haunt the world if his case is not solved and the guilt and responsibility concerning his disappearance and death are not admitted. Garôar is thus 'guilty' in a double sense, not only of the couple's economic stress and of betraying his wife, but also because, despite the severity of the social breakdown, Garoar is still aspiring to the idea of the dominant masculine hero. Katrín, in her passiveness, becomes partially responsible by not taking action. Líf did not cause the crash, but her husband got rich during the expansion and she benefits from that, without having any feelings of remorse nor being ready to assist her less fortunate fellow men. And it ends badly for all of them; Garoar disappears, Líf dies, and Katrín returns as a spectral subject to the house in Hesteyri. Her anger, furthermore, implies how she returns as a more active subject, looking for revenge, or rather, seeking justice, by haunting those who are guilty, who have something on their conscience and should face the responsibility of their actions in the past.

\section{TO CONCLUDE}

The financial crash in Iceland 2008 is an example of a collective shock and an event that challenges collective memory, creating the possibility to expose its inherent tensions, workings, and dynamics. The crisis that followed was a period of spectral mourning; a process that becomes highly ambiguous since subjects do not entirely understand what it is that they mourn. Analysing the cultural responses to the crash, the literature and visual art of the period, might help to understand this moment of spectral mourning and the reasons behind the 'impossible' grief. While the analysis of the crime novel indicates how the characters are stuck in their melancholic, inactive state due to their financial loss that also represents their loss of identity and future, the drawings have the potential of spectralising these feelings of loss further and problematizing ideas of 'collective' loss and mourning, by asking the following question: who is haunted and by whom? In this sense, I argue that the invisible worker is a spectral force who haunts the images by questioning the symbol of the "business Viking" as a unifying ideal capable of representing the many different cultural groups of the pre-crash society. It becomes a force that complicates the idea of collective mourning, and, to a certain degree, deconstructs it, by drawing attention to how the collapse and crisis have had a different impact on different social groups in the Icelandic society. 
1 Jón Gunnar Bernburg, Economic Crisis and Mass Protest: The Pots and Pans Revolution in Iceland (London \& New York: Routledge, 2016), 2.

2 Aleric Hall uses the word 'Crash' with a capital C, to indicate the moment when the Icelandic banks collapsed: "The economic crisis this wrought is generally referred to in Icelandic as the hrun, literally 'collapse' (also kreppa 'difficulty, tight spot')-hereafter rendered in this book as the Crash." Útrásarvíkingar; The Literature of the Icelandic Financial Crisis (2008-2014) (Santa Barbara, CA: punctum books, 2020), 8.

3 Bernburg gives a good overview of the events in October 2008 in his introduction, Bernburg, Economic Crisis and Mass Protest, 1-16.

4 There are few exceptions to this: Aleric Hall gives a broad account of the literature published in the wake of the crash and crisis in Útrásarvíkingar: a BA thesis by Guơún Baldvinsdóttir, “'Hver á sér fegra föđurland?' pjódarsjálfsmynd i íslenskum hrunbókmenntum" from 2014; a website created by Jón Karl Helgason and Guơni Th. Jóhannesson, professors at the University of Iceland, following a course they taught on the subject: "Hrunio, piơ munió: Ráostefnuvefur - gagnabanki", University of Iceland. Accessed June 15, 2020. http://hrunid.hi.is/ skaldskapur/.

5 Yrsa Sigurðardóttir, Ég man pig (I Remember You) (Reykjavík: Veröld, 2010).

6 Guojón Ketilsson, untitled, 2009, pencil on paper, 40x40 $\mathrm{cm}$. Courtesy of National Gallery of Iceland.

7 Richard Davenport-Hines, Gothic: Four Hundred Years of Excess, Horror, Evil and Ruin (New York: North Point Press, 1998), 3-4.

8 Esther Peeren, The Spectral Metaphor: Living Ghosts and The Agency of Invisibility (New York: Palgrave Macmillan, 2014).

9 Jacques Derrida, Specters of Marx: The State of Debt, The Work of Mourning, and the New International, trans. Peggy Kamuf (New York: Routledge, 1994).

10 Peeren, The Spectral Metaphor, 14.

11 Ibid., 17.

12 Derrida, Specters of Marx, 101-102.

13 Ibid., xviii.

14 Peeren, The Spectral Metaphor, 20.

15 Antonio Negri, "The Specter's Smile," in Ghostly Demarcations: A Symposium on Jacques Derrida's Specters of Marx, ed. Michael Sprinker (London: Verso, 1999), 5-16. Negri's point of departure is the spectre as discussed by Marx in his writings: "Transferred onto the terrain of the critique of political economy, this project of spectral reading of ideology is applied to the categories of society and capital, develops ontologically, and becomes definitively fixed in Capital." (6). The spectre, for Negri, is above all the offspring of capitalist society: "The 'specters of Marx' are therefore, in some way, the specters of capital. Those specters that appear in Capital, but above all, those specters that nowadays give shape to a society unanimously defined as 'capitalist' by political economy and public opinion." (6).

16 Ibid., 7.
17 Valur Ingimundarson, "The Politics of Transition, Memory, and Justice: Assigning Blame for the Crisis," in Iceland's Financial Crisis: The Politcs of Blame, Protest and Reconstruction, ed. Valur Ingimundarson, Philippe Urfalino, Irma Erlingsdóttir (New York: Routledge, 2016), 143.

18 Guơni Elísson, "Vogun vinnur ...: hvar liggja rætur íslenska fjármálahrunsins," in Saga 2009, 47 (2), 129.

19 Ingimundarson, "Narrating Iceland's Financial Crisis: Contested Memories of Blame, Justice and Reconstruction," in Alexander Drost, Olga Sasunkevich, Joachim Schiedermair, and Barbara Tornquist-Plewa, eds., Collapse of Memory, Memory of Collapse: Narrating Past Presence and Future about Periods of Crisis (Cologne: Böhlau Verlag, 2019), 113; and Gunnpórunn Guômundsdóttir, "The Black Cone. Memory and Memorialisation in Post-Recession Iceland," ibid., 146.

20 Ibid., 112-113. Ingimundarson describes how the report was an answer to the demand of seeking accountability for the economic collapse, and how its publication was highly anticipated by the public.

21 Ibid., 117.

22 Ibid., 117.

23 Guðmundsdóttir speaks of "a memorial of contested past" (139) in her discussion of the crash and the sculpture Black Cone, and Ingimundarson uses the term in the title of his article: "Narrating Iceland's Financial Crisis: Contested Memories of Blame, Justice and Reconstruction" while he also conceptualises the crash as a collective shock, struggle, even trauma, when he states that the politics in Iceland are still haunted by the "trauma" of the crash (111-112).

24 John R. Gillis, "Introduction: Memory and Identity: History of a Relationship," in Commemorations: the politics of national identity, ed. John R. Gillis (Princeton, N.J.: Princeton University Press, 1994), 3.

25 "But it is also partly because Icelanders have realised that to understand the mentalities behind the Crash itself, it is necessary to understand the relationship between Icelandic identities and the sometimes farflung Danish empire to which Iceland once belonged, as well as the neo-imperialism of the USA other European countries - that is, the mutated forms that nineteenthcentury colonial imperialism has taken as countries seek to achieve the extractive economic dominance once associated with empire without actually using direct rule, or indeed admitting (even to themselves) to having a colonial agenda. Postcolonial thought is necessary to understand how Iceland has both been a victim of imperialisms old and new, but also a participant in them, and indeed a beneficiary." Hall, Útrásavíkingar!, 48.

26 Ingimundarson, interview he gave at a symposium on the responsibility of the University in the events of the crash, in a newspaper: Karl Blöndal “'Fyrsta heims ríki' í 'priðja heims stöðu' Í kjölfar hrunsins takast Íslendingar á vio fortíoina," November 22, 2009 in Morgunbladid. Accessed June 15, 2020. http://www.mbl.is/greinasafn/ grein/1311272.

27 Bernburg, 3-4. 
28 Kristín Loftsdóttir, “Kjarnmesta fólkio í heimi: Prástef íslenskrar bjódernishyggju í gegnum lýoveldisbaráttu, útrás og kreppu," in Ritid 2-3/2009, 113.

29 Elísson, "Vogun vinnur", 123.

30 Ibid., 124.

31 Loftsdóttir, “Kjarnmesta fólkið”, 114.

32 Ibid., 117.

33 Ibid., 118.

34 Ibid., 113.

35 Ibid., 118.

36 Academics have however critiqued this assumption of trauma being the core of memory and Andreas Huyssen, for example, stresses that memory and trauma should not be equated: "It has been all too tempting to some to think of trauma as the hidden core of all memory. [...] both are marked by instability, transitoriness, and structures of repetition. But to collapse memory into trauma ... would unduly confine our understanding of memory, marking it too exclusively in terms of pain, suffering and loss." Present Pasts: Urban Palimpsest and the Politics of Memory, (Palo Alto, CA: Stanford, 2003), 8. Maria Del Pilar Blanco and Esther Peeren, "Introduction: Conceptualizing Spectralities," in The Spectralities Reader: Ghosts and Haunting in Contemporary Cultural Theory, (New York \& London: Bloomsbury, 2013), 13.

37 Hall, Útrásarvíkingar!, 55.

38 Dynamics is a key concept in contemporary cultural memory studies and stresses how memory should be conceptualised as a process or a movement instead of a phenomenon that is static in time and space, and where forgetting is an integral part of memory and as important as remembering. On the dynamics of cultural memory see for example Astrid Erll and Ann Rigney, "Introduction: Cultural Memory and its Dynamics" in Mediation, Remediation and the Dynamics of Cultural Memory, ed. Erll and Rigney with Laura Basu and Paulus Bijl (Berlin and Boston: Walter de Gruyter GmbH \& Co. KG, 2012), 1-14, 2. On the important part of forgetting in memory see Gunnpórunn Guðmundsdóttir, Representations of Forgetting in Life Writing and Fiction (London: Palgrave Macmillan, 2017), 2.

39 Derrida, Specters of Marx, 15.

40 "the ghost as figure of trauma has become almost a cliché, reinforced as it was throughout the 1990 s by an elaborate critical discourse of spectres and 'spectrality"” Luckhurst, Trauma Question, 93. Del Pilar Blanco and Peeren, The Spectralities Reader, 15.

41 Sigmund Freud, "Mourning and Melancholia," (1917) trans. Michael Hulse, in On Murder, Mourning and Melancholia (London: Penguin, 2005), 201-218.

42 Daniela Agostinho, Elisa Antz, and Cátia Ferreira, "Introduction," in Panic and Mourning, the Cultural Work of Trauma (Berlin: Walter De Gruyter GmbHKG, 2012), 1.

43 "Successful mourning, in Freud's reasoning, implies 'working through' grief and liberating the subject from the lost object in order for it to find a new object of attachment. [...] However, contemporary critics have come to question the ethical and political desirability of mourning, in that it promotes forgetting, normative conciliation, and an abdication of responsibility. Melancholia, in turn, could emerge as resistance to the normative work of mourning, keeping the memory of the deceased alive and encouraging a critical and unsettling remembrance that does not comply with the conventionalised acceptation of loss and the containment of anxiety or the suppression of problematic memories in society" Agostinho, Antz, and Ferreira, "Introduction," in Panic and Mourning, 1-2.

44 Ibid., 2. Here the authors are referring to Specters of Marx.

45 Peeren and del Pilar Blanco, "Introduction: Conceptualising Spectralities," in The Spectralities Reader (16). The Editors further discuss how the ghost for Freud is above all 'gruesome' and how innovatively Derrida uses its metaphorical possibilities to conceptualise it as an 'revenenant' and 'arrivant' (13).

46 This news story tells how for the first time Arnaldur Indriðason, the king crime writer in Iceland, lost the top seller spot to Yrsa: "Arnaldur missti toppsætið til Yrsu," in Vísir.is, 8 December 2011. Accessed April 12, 2019. https://www.visir.is/g/2011712089917. This news story from the national radio and TV broadcast in Iceland is written in March 2011 and states that I Remember You is the number one bestseller in Iceland that year: "Ég man pig söluhæst", RÚV, 16 March, 2011. Accessed April 12, 2019. http://www.ruv.is/frett/eg-man-thig-soluhaest.

47 I mention the film adaptation in order to emphasize the popularity of the book, but the crisis aspect is diminished in the film and the storyline extensively altered. The film is therefore not part of the analysis here.

48 "Gardar wouldn't have been better off with her dead ... then she remembered their life insurance." Yrsa, Sigurðardóttir, I Remember You, transl. Philip Roughton (London: Hodder \& Stoughton, 2012), 359, Kindle.

49 Sigmund Freud, "The Uncanny," (1919) trans. Alix Strachey, in Writings on Art and Literature (Stanford: Stanford University Press, 1997), 217.

50 Sigurðardóttir, I Remember You, 372.

51 Ibid., 39

52 Freud, "The Uncanny", 218.

53 Sigurðardóttir, I Remember You, 361.

54 Ibid., 361.

55 This is actually the title of his book: Gothic: Four Hundred Years of Excess, Horror, Evil and Ruin.

56 lbid., 8.

57 Ibid., 8. Here he refers to Mark Edmundson, Nightmare on Main Street: Angels, Sadomasochism and the Culture of Gothic (Cambridge, Mass: Harvard University Press, 1997).

58 Ibid., 2.

59 lbid., 8.

60 Sigurðardóttir, I Remember You, 40.

61 When the trio think they are dealing with a disturbed child and not a ghost, Garðar, as opposed to Katrín, shows no empathy, as he describes it as "strange" and hopes it will "perish in the storm" outside the house (ibid., 139).

62 Sigurðardóttir, I Remember You, 164.

63 Ibid., 187.

64 Ibid., 359.

65 Ibid., 326.

66 Ibid., 370.w 